\title{
Screening Some Tef [Eragrostis Tef (Zucc.)Trotter] Accessions/Varieties for Salt Tolerance during Germination and Seedling Stage
}

\author{
*Kinfemichael Geressu Asfaw ${ }^{1}$ and Fisseha Itanna ${ }^{2}$ \\ ${ }^{1}$ Department of Biology, College of Natural and Computational Sciences, Mekelle \\ University, P.O. Box 231, Mekelle, Ethiopia (*kinfe_michael2006@yahoo.com) \\ 2 Department of Biology, Addis Ababa University, P.O. Box 1176, Addis Ababa, Ethiopia \\ (fissehai@yahoo.com)
}

\begin{abstract}
Salinity is a continuing problem in the arid and semi-arid tracts of the world. It could be alleviated using irrigation management and/or crop management. However, the former approach is outdated and very expensive. Nevertheless, the latter is economical as well as efficient, and it enables to produce salt tolerant crop lines. But prior to that there is a need to confirm the presence of genetic based variation for salt tolerance among different species or varieties of a particular crop that can thrive under unreliable agro-ecological situations; tef [Eragrostis tef (Zucc) Trotter] is one of such crops. Thus fifteen lowland tef genotypes (10 accessions and 5 varieties) were tested during germination and seedling stage at $2 \mathrm{dS} / \mathrm{m}, 4 \mathrm{dS} / \mathrm{m}, 8 \mathrm{dS} / \mathrm{m}, 12 \mathrm{dS} / \mathrm{m}$ and $16 \mathrm{dS} / \mathrm{m}$ salinity levels. Distilled water $(0 \mathrm{dS} / \mathrm{m})$ was used as a control. Data analysis was carried out using SAS package. Germination percentage (GP), germination rate (GR), seedling shoot length (SSL) and seedling root length (SRL) were measured. The analyzed data showed significant variation among most parameters recorded for accessions and varieties $(p \leq 0.01)$ and for treatments $(\mathrm{p} \leq 0.001)$. Germination rate and seedling root length were more salt affected than final germination percentage and seedling shoot length respectively. The main cause for reduced and delayed germination percentage was osmotic effect. The ion effect was also learned to be minimal. Most accessions and varieties failed to germinate at $12 \mathrm{dS} / \mathrm{m}$ and $16 \mathrm{dS} / \mathrm{m}$ salinity levels. Thus, these salt concentrations were not important in screening tef genotypes for salt tolerance. Varieties such as DZ-01-1281, DZ-Cr-358 and accession 236512 were found to be salt sensitive. However, variety DZ-Cr-37 and accessions 237186, 237131 and 212928 were found to be salt tolerant. The rest accessions and varieties were intermediate in their salt tolerance. The study affirmed the presence of broad intraspecific variation among tef accessions and varieties for salt tolerance but more in the former.
\end{abstract}

Key words: Accessions, Germination, $\mathrm{NaCl}$, Salinity, Eragrostis tef.

\section{INTRODUCTION}

Salt-affected soils are found throughout the world. That is why Brandy and Weil (2002) claimed that no continent is free from the problem. Salt-affected soils are serious threats to crop production in the arid and semi-arid tracts of the world (Verma and Yadava, 1986). Globally, a total land area of 831 million hectares is salt-affected. African countries like Kenya (8.2Mha), Nigeria (5.6Mha), Sudan (4.8Mha), Tunisia (1.8Mha), 
Tanzania (1.7Mha) and Ghana (0.79Mha) are salt-affected to various degrees (FAO, 2000).

In Ethiopia, salt-affected soils are prevalent in the Rift Valley and the lowlands. The Awash Valley in general and the lower plains in particular are dominated by salt-affected soils (Tadele Gebresellassie, 1993). For example, soil salinity has caused a significant abandonment of banana plantation and showed a dramatic spread to the adjacent cotton plantation of Melka Sadi Farm (Fentaw Abegaz, 1995). Studies by Hailay Tsige et al. (2000) also indicates that of the entire Abaya State Farm, 30\% has already been saltaffected. This problem is expected to be severe in the years to come. This is because under the prevailing situation of the country, there is a tendency to introduce and implement large-scale irrigation agriculture so as to meet the demands of the everincreasing human population by elevating productivity (Tekalign Mamo et al., 1996). In the absence of efficient ways of irrigated water management, salt build up is an inevitable problem.

The possible solution is either using physical practice (irrigation frequency and leaching, irrigation methods, cyclic use of multi-quality waters, fertility management and amendments) or biological practice (attainment of salt tolerant species and cultivating through biological approaches) (Gupta and Minhas, 1993). Since physical practice (irrigation management) is not economically feasible, according to El-Khashab et al., (1997), there is a need to concentrate on the biological approach or crop management (Ashraf and McNeilly, 1988). Nevertheless, to proceed with this approach, affirming the presence of genetic based variation for salt tolerance in a particular crop is a requisite (Marler and Mickelbart, 1993).

Thus in doing so, one has to focus on crops that have been cultivated for a long period of time in a country, and are able to provide reliable yield under unreliable agro-climatic conditions and make ranking first against area coverage, demand and market value. Tef [Eragrostis tef (Zucc) Trotter] is one of such crops, which has been cultivated in the country as a cereal crop for quite long (Purseglove, 1972). Furthermore, tef can be adapted to a broader range of agro-climatic environments. It can grow in altitudes ranging from sea level to 2800 m.a.s.l, under different moisture, soil, temperature and rainfall regimes. It can tolerate anoxic situations better than maize, wheat and sorghum. It has 
ease of storage, tolerance to weevils and other pests. The straw is preferred to any other cereal straws and can fetch premium price (Seyfu, 1993). According to Mengesha et al.(1965), it contains higher amount of a number of minerals than wheat, barley or grain sorghum. As compared to other cereals, the largest cultivated land area is covered by tef. Moreover, the area used for tef production is increasing from time to time (Hailu and Seyfu, 2000). For example, it covered 1,818, 375 (in 2001/02) and 1,989,068 (2003/04) hectares of land which is 28.5 and 28.4 percent of the area covered respectively by the whole cereals in each production year (CSA, 2004). Generally, tef is a reliable cereal an under unreliable climate. That is why, in many areas where recurrent moisture stress occurs, tef production replaces the production of maize and sorghum (Seyfu Ketema, 1993).

Therefore, this article attempted to screen 15 genotypes (10 accessions and 5 varieties) of tef [Eragrostis tef (Zucc.)Trotter] in the germination and seedling stage.

\section{MATERIALS AND METHODS}

Seeds of 10 tef accessions were obtained from the Institute of Biodiversity Conservation (IBC) whereas 5 tef varieties were supplied by Debre Zeit Agricultural Research Center (DZARC), Ethiopia. The specific tef genotypes used in the research were accessions 55017, 205217, 212611, 212928, 229747, 231217, 236512, 236514, 237131, 237186, and varieties DZ-Cr-358, DZ-01-196, DZ-01-1281, DZ-01-168 and DZ-Cr-37. The accessions were adapted to altitude ranging from 1150 - 1550 meters a.s.l. where as the varieties were adapted to altitudes from 1400 - 2400 meters a.s.l.

Germination experiment was conducted from December 14, 2003 to January 24,2004 at Melkassa Agricultural Research Centre (MARC) using a 1996 model Fitotron Plant Growth Chamber where $75 \%$ relative humidity, $20^{\circ} \mathrm{C}$ temperature, $114 \mu \mathrm{molm}^{-2} \mathrm{sec}^{-1}$ incandescent and florescent light and 12 hours day/night duration were maintained (Azhar and McNeilly,1987). The experiment assessed the germination response of tef genotypes to different $\mathrm{NaCl}$ salinity levels. The $\mathrm{NaCl}$ concentrations used were $2 \mathrm{dS} / \mathrm{m}$, $4 \mathrm{dS} / \mathrm{m}, 8 \mathrm{dS} / \mathrm{m}, 12 \mathrm{dS} / \mathrm{m}$ and $16 \mathrm{dS} / \mathrm{m}$; distilled water $(0 \mathrm{dS} / \mathrm{m})$ was used as a control. These salinity levels were obtained by dissolving $1.17 \mathrm{~g}, 2.34 \mathrm{~g}, 4.68 \mathrm{~g}, 7.02 \mathrm{~g}$ and $9.36 \mathrm{~g} \mathrm{NaCl}$ in one litre distilled water respectively. Glass petri dishes with a diameter of $10 \mathrm{~cm}$ were 
lined with Whatman No.3 filter paper and were arranged in a randomized complete block design (RCBD) with four replications. Each petri dish was supplied with $5 \mathrm{ml}$ of the respective treatment solution. In such a way 20 tef seeds were planted. Treatment application was made continued every other day and germination count was started after 72 hours of sowing and continued until the $13^{\text {th }}$ day. A seed was considered to have germinated when both the plumule and the radicle emerged $\geq 0.5 \mathrm{~cm}$. After 13 days, overall shoot and the longest root length of ten randomly selected seedlings from each replicate were measured using a draftsman ruler (Azhar and McNeilly, 1987).

Germination rate (GR): the average number of days needed for plumule or radicle emergence was calculated as (Lemma Desalegne, 1996):

$\mathrm{NT}_{3}+\mathrm{NT}_{6}+\mathrm{NT}_{9}+\mathrm{NT}_{12}$

Germination rate $(\mathrm{GR})=\overline{\text { Total number of seeds germinated }}$

Where: $\quad T_{n}=$ number of seeds germinated at day 3, 6, 9, 12

$$
\mathrm{N}=\text { days }(3,6,9,12)
$$

Similarly, seedling shoot-to-root ratio (SRR) was calculated as the ratio of seedling shoot length (SSL) to seedling root length (SRL).

\section{STATISTICAL ANALYSIS}

Data analysis was carried out by SAS package where two ways analysis of variance (ANOVA) and correlation analysis were employed. Prior to data analysis, shoot-to-root ratio (SRR) was log transformed. At $12 \mathrm{dS} / \mathrm{m}$ and $16 \mathrm{dS} / \mathrm{m}$, almost all accessions and varieties collapsed after germination. Consequently, the incomplete data obtained from these salinity levels had been excluded from the data analysis of germination rate (GR), seedling shoot length (SSL), seedling root length (SRL) and shoot-to-root ratio (SRR).

\section{RESULTS}

\subsection{Final Germination Percentage (FGP)}

The analysis of variance (ANOVA) showed significant variation for accessions and varieties $(\mathrm{p} \leq 0.001)$ and treatments $(\mathrm{p} \leq 0.001)$. Genotype * treatment interaction effect was also found to be significant ( $\mathrm{x} \leq$ 0.001). Except variety DZ-Cr-358 all genotypes 
(both accessions and varieties) achieved more than 85\% final germination percentage at 2dS/m. Moreover, this salt concentration stimulated seed germination in variety DZ-011681. At $4 \mathrm{dS} / \mathrm{m}$, all accessions and varieties attained more than $75 \%$ final germination percentage (FGP) except accession 236514 (56\%) and variety DZ-01-1281 (32.5\%). At 8dS/m, varieties like DZ-01-1281(5\%) and DZ-Cr-358 (10\%) and accessions 236514 (30\%), 236512 (25\%) and 231217 (35\%) achieved only from 5 to 35\% final germination percentage (FGP). However, the rest accessions and varieties attained from 40 to $91.3 \%$ final germination percentage (FGP). At $12 \mathrm{dS} / \mathrm{m}$, tef genotypes germinated from $7.5 \%$ to $83.8 \%$ but variety DZ-01-1281 failed to germinate. On the other hand, at $16 \mathrm{dS} / \mathrm{m}$ the final germination percentage reduced from 50 to $98.7 \%$ and accession 231217 and variety DZ-01-1281 failed to germinate.

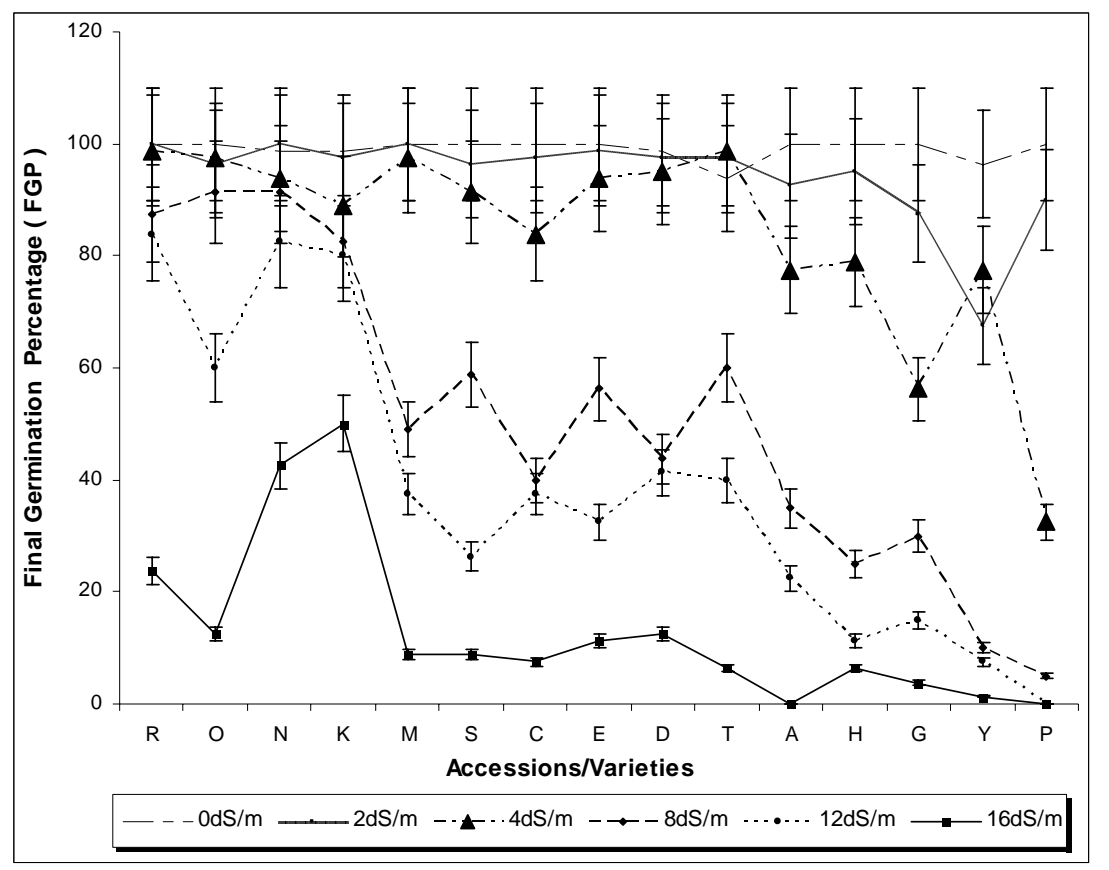

Figure 1. Effects of different salinity levels $(0,2,4,8,12$ and $16 \mathrm{dS} / \mathrm{m})$ on final germination percentage (FGP) of tef [Eragrostis tef (Zucc.)Trotter] accessions and varieties. (Key to accessions: $\mathrm{A}=231217, \mathrm{C}=212611, \mathrm{E}=229747, \mathrm{G}=236514, \mathrm{H}=$ 236512, $\mathrm{M}=55017, \mathrm{~N}=237186, \mathrm{O}=237131, \mathrm{R}=212928$ and $\mathrm{S}=205217$; Key to varieties: $\mathrm{D}=\mathrm{DZ}-01-196, \mathrm{~K}=\mathrm{DZ}-\mathrm{Cr}-37, \mathrm{P}=\mathrm{DZ}-01-1281, \mathrm{~T}=\mathrm{DZ}-01-168$ and $\mathrm{Y}=\mathrm{DZ}-$ Cr-358).

Every salinity level resulted in reduced germination percentage in most accessions and varieties. Nevertheless, the drop was sharp and rapid in accessions like 236512, 232117 
and 236514 as well as in varieties such as DZ-Cr-358 and DZ-01-1281 at 8dS/m, 12dS/m and 16dS/m salinity levels (Fig. 1).

\subsection{Germination Rate (GR)}

The analysis of variance (ANOVA) for germination rate (GR) showed significant variation among accessions $(\mathrm{p} \leq 0.001)$ and treatments $(\mathrm{p} \leq 0.001)$. Every salt treatment delayed the emergence of plumule and radicle compared to the control. However, the influence became pronounced with higher salt concentrations (Fig.2). From the entire genotypes considered, accessions 231217 and 236514, and varieties DZ-01-1281 and DZ-Cr-358 were the most salt-affected as compared to the control. However, accessions 212928, 237131, 237186 and variety DZ-Cr-37 were the least salt-affected genotypes.

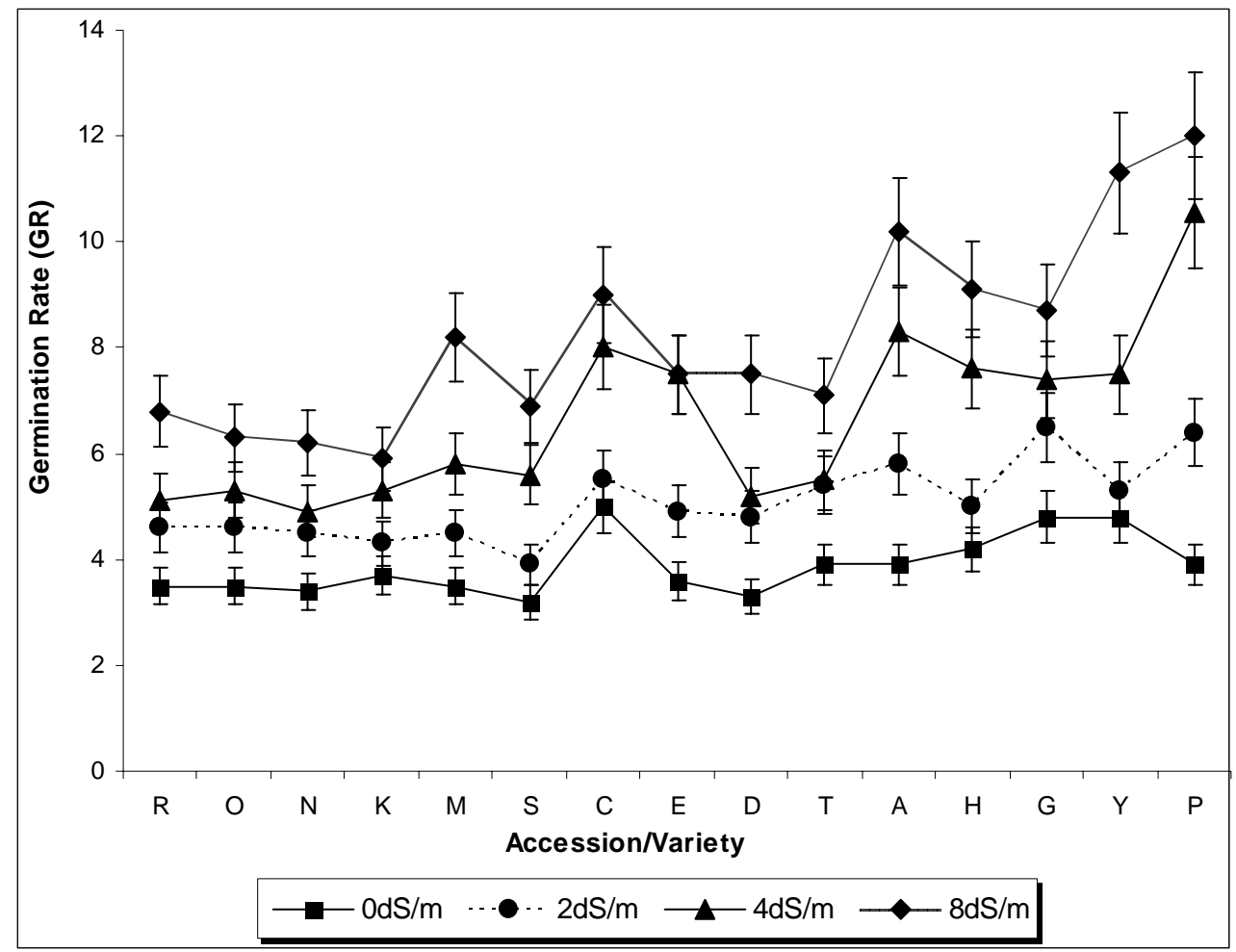

Figure 2. Effects of different salinity levels (0, 2, 4 and $8 \mathrm{dS} / \mathrm{m})$ on germination rate (GR) of tef [Eragrostis tef (Zucc.)Trotter.] accessions and varieties. (Key to accessions: $\mathrm{A}=$ 231217, $\mathrm{C}=212611, \mathrm{E}=229747, \mathrm{G}=236514, \mathrm{H}=236512, \mathrm{M}=55017, \mathrm{~N}=237186, \mathrm{O}$ = 237131, $\mathrm{R}=212928$ and $\mathrm{S}=$ 205217; Key to varieties: $\mathrm{D}=\mathrm{DZ}-01-196, \mathrm{~K}=\mathrm{DZ}-\mathrm{Cr}-37$, $\mathrm{P}=\mathrm{DZ}-01-1281, \mathrm{~T}=\mathrm{DZ}-01-168$ and $\mathrm{Y}=\mathrm{DZ}-\mathrm{Cr}-358)$.

\subsection{Average Seedling Shoot Length (SSL)}

The analysis of variance (ANOVA) revealed significant variation among accessions $(\mathrm{p} \leq$ 0.001) and treatments $(\mathrm{P} \leq 0.001)$ for average seedling shoot length (SSL). 
Genotype*treatment interaction effect was also significant $(\mathrm{P} \leq 0.01)$ reflecting all the accessions and varieties responding differently to salt stress with respect to average seedling shoot length (SSL). Increased salinity levels resulted in a decreased average seedling shoot length (SSL) in accessions 231217, 236512 and 236514 and varieties DZCr-358 and DZ-01-1281. Nevertheless, average seedling shoot length (SSL), brought about no influence in accessions 212928, 237131 and 237286 and varieties DZ-01-196, DZ-01-1681 and DZ-Cr-37 by salt stress up to 8dS/m.

\subsection{Average Seedling Root Length (SRL)}

The analysis of variance (ANOVA) confirmed the presence of significant variation in average seedling root length $(\mathrm{SRL})$ among genotypes $(\mathrm{P} \leq 0.001)$ and treatments $(\mathrm{P} \leq$ 0.001). Lower salt concentrations caused stimulated seedling root length (SRL). For example, average seedling root length (SRL) was stimulated at $2 \mathrm{dS} / \mathrm{m}$ in accessions 205217, 237131 and 237186 and at both 2dS/m and 4dS/m in variety DZ-Cr-37. Nevertheless, higher salt concentrations resulted in a reduced average seedling root length (SRL). At 8dS/m a reduction of 72.7, 73, 75, 87.5 and 88.9 percent was observed in accessions 236514, 236512, 231217 and varieties DZ-01-1281 and DZ-Cr-358 respectively as compared to the control. On the other hand, average seedling root length (SRL) of accession 237186 and 212928, variety DZ-Cr-37, accession 237131 and variety DZ-01-1681 decreased by 31.9, 38.6, 44.7, and 48.8 percent respectively at $8 \mathrm{dS} / \mathrm{m}$ salinity level as compared to the control.

\subsection{Seedling Shoot-To-Root Ratio (SRR)}

The analysis of variance (ANOVA) for seedling shoot-to-root length ratio (SRR) depicted significant variations for accessions/varieties $(\mathrm{P} \leq 0.001)$ and treatments $(\mathrm{P} \leq$ 0.001). Genotype* treatment interaction effect was also learned to be significant $(\mathrm{P} \leq$ 0.001). This reflects that accessions and varieties responded to salt stress differently with respect to seedling shoot-to-root ratio (SRR). As the salinity level increased, SRR showed increment compared to the controlled part. This was quite pronounced in accessions 229747 (80\%), 231217 (70.77\%), 236512 (70\%) and 236514 (64.47\%) as well as in varieties DZ-Cr-358 (81.88\%) and DZ-01-1281 (81.54\%) (Fig.3). Nevertheless, in accessions 212928 (40.63\%) and 237186 (35.14\%) the increment in SRR as a result of higher salt concentration $(8 \mathrm{dS} / \mathrm{m})$ was minimal. 


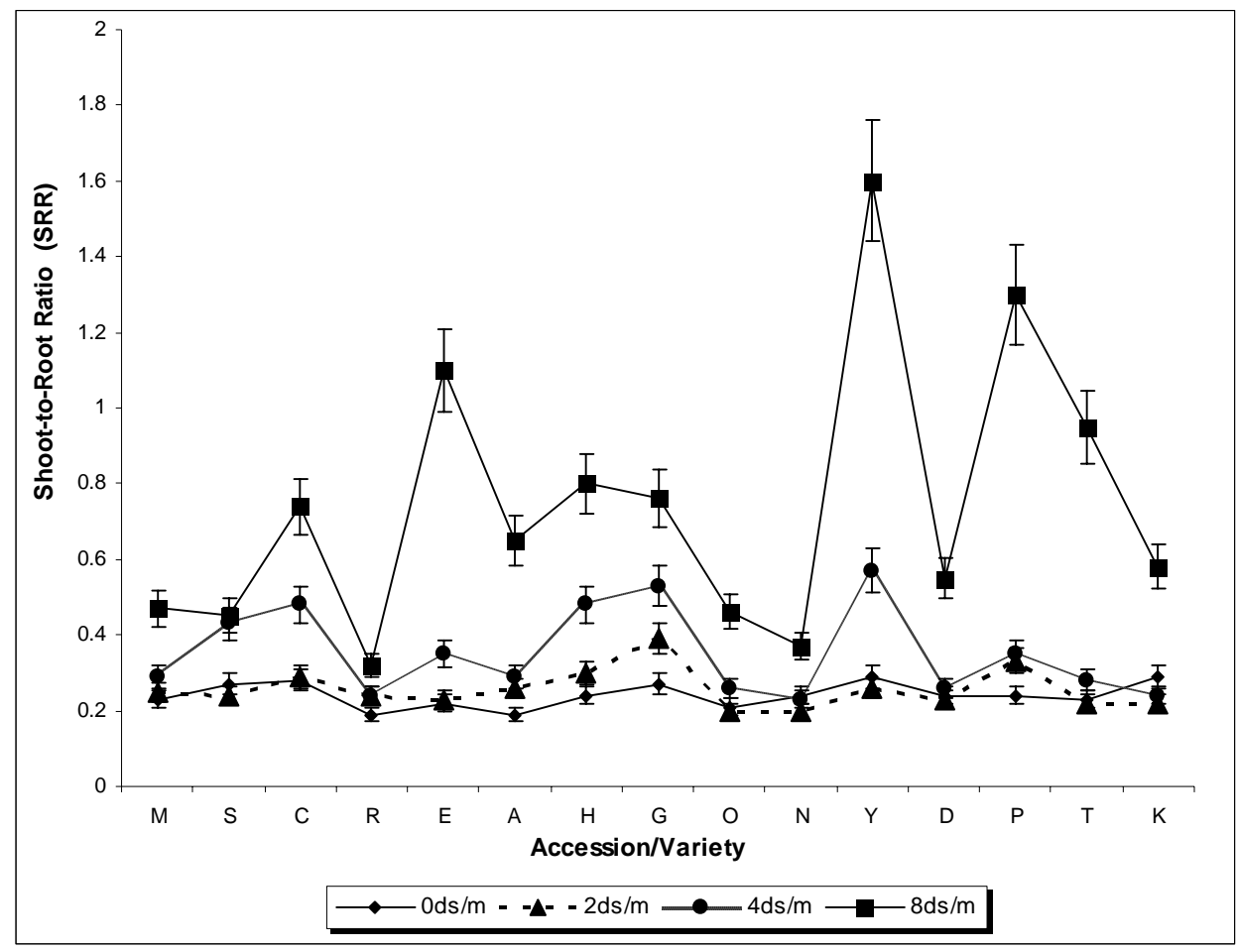

Figure 3. Effects of different salinity levels $(0,2,4$ and $8 \mathrm{dS} / \mathrm{m})$ on seedling shoot-toroot length ratio (SRR) of tef [Eragrostis tef (Zucc.)Trotter.] accessions and varieties. Key to accessions: $\mathrm{A}=231217, \mathrm{C}=212611, \mathrm{E}=229747, \mathrm{G}=236514, \mathrm{H}=236512, \mathrm{M}=$ 55017, $\mathrm{N}=237186, \mathrm{O}=237131, \mathrm{R}=212928$ and $\mathrm{S}=205217$; Key to varieties: $\mathrm{D}=\mathrm{DZ}-$ 01-196, K = DZ-Cr-37, P = DZ-01-1281, T = DZ-01-168 and Y = DZ-Cr-358).

\subsection{Correlation Analysis}

The correlation analysis showed a positive and significant correlation between average seedling shoot length (SSL) and average seedling root length (SRL), and between germination rate (GR) and seedling shoot-to-root ratio (SRR) $(\mathrm{P}<0.001)$. Furthermore, final germination percentage (FGP) was significantly and positively correlated with both average seedling shoot length (SSL) and average seedling root length (SRL). On the other hand, average seedling root length (SRL) and final germination percentage (FGP) depicted a negative and significant correlation with seedling shoot-to-root ratio (SRR) and germination rate $(\mathrm{GR})(\mathrm{P}<0.001)$.

\section{DISCUSSION}

The positive significant correlation between SSL and SRL as well as between GR and SRR indicates that tef genotypes responded to salt stress more or less in a similar manner 
with respect to these parameters. The negative significant correlation between GR and SRL might imply that the extended exposure of a particular genotype to salt stress could cause the entrance of excessive $\mathrm{Na}^{+}$and $\mathrm{Cl}^{-}$into the cells (Dudeck et al., 1983). This might disturb membrane integrity owing to the replacement of $\mathrm{Ca}^{2+}$ by $\mathrm{Na}^{+}$(Suhayda et al., 1992) and in turn, it might lead to further entrance of $\mathrm{Na}^{+}$and out flow of important ions such as $\mathrm{K}^{+}$(Ashraf and Waheed, 1993). On the other hand, the insignificant negative correlation between SSL and GR reflects that there was no excessive entrance of $\mathrm{Na}^{+}$into shoot cells. So, the average seedling root length (SSL) was more salt-affected than the average seedling shoot length (SSL). This is evident from the significant negative correlation between SRL and SRR as well as from the increment of SRR in response to increased salt concentration.

Final germination percentage (FGP) was reduced by every salt treatment in most genotypes. Likewise, similar results were reported in triticale (Norlyn and Epstein, 1983), oats (Verma and Yadava, 1986), rice (Lee et al., 1998), durum wheat and tef (Tekalign Mamo et al., 1996). Every salt treatment has delayed germination rate the effect being more pronounced with higher salt concentrations. This is in agreement with reports in intermediate wheat grass (Hunt, 1965), spring wheat (Ashraf and McNeilly, 1988), pearl millet (Singh et al., 1999), perennial rye grass (Horst and Dunning, 1989), and sorghum (Marambe and Ando, 1995). Moreover, the delay was remarkable in sensitive and intermediate accessions as compared to the tolerant genotypes. Germination rate was more salt-affected than final germination percentage, which is consistent with previous report in triticale (Francois et al., 1988).

Crop genotype may germinate effectively under salt stress; nevertheless, its seedling growth will be affected (Azhar and McNeilly, 1987). Contrary to this, accessions 237186, 237131 and variety DZ-Cr-37 that were the most salt tolerant genotypes in terms of final germination percentage (FGP) and germination rate (GR) showed promising seedling growth. It has already been reported that plant growth and development is dependent on crop stand establishment (Verma and Yadava, 1986), in turn the latter is a function of effective germination (Horst and Taylor, 1983) and seedling growth (Ashraf and Wheed, 1992). Crops with higher germination percentage and low germination rate can establish themselves effectively on moderately saline soils (with $2 \mathrm{dS} / \mathrm{m}$ - 10dS/m electrical 
conductivity) (Lee et al., 1998). Thus, even if it is difficult to extrapolate the research result obtained from controlled laboratory experiment directly to the field, the above genotypes have salt tolerance which enables them to germinate and establish on moderately saline areas. Consequently, this would help to minimize grain yield loss that could emanate from inadequate crop stand establishment as a result of poor germination and seedling growth. Thus these genotypes have agricultural significance for the entire world in general and for the country in particular.

Contrary to Gorham and Hardys' (1990) generalizations that tef is salt sensitive and unable to regulate the influx of salt ions such as $\mathrm{Na}^{+}$and $\mathrm{Cl}^{-}$even at very low salinity levels; variety DZ-Cr-37 and accessions 212928 and 237186 were able to attain more than $75 \%$ final germination percentage (FGP) at $12 \mathrm{dS} / \mathrm{m}$. In contrast to previous report in soybean (Abel and McKenzie, 1964), a broad intraspecific variation among tef accessions and varieties was obtained with the variations more pronounced in the former. Therefore, this would allow more salt tolerant lines to be selected from the existing tef germplasm. Salinity is a growing problem worldwide. Thus to alleviate the existing and the upcoming problems, there should to be similar and profound studies on tef and other crops.

\section{ACKNOWLEGEMENTS}

The authors are grateful to RPSUD (Research Programme for Sustainable Use of Dryland Biodiversity) for financial assistance and MARC ( Melkassa Agricultural Research Center) for equipment and laboratory provision. Moreover, we are indebted to IBC (Institute of Biodiversity Conservation) and DZARC (Debre Zeit Agricultural Research Center) for supplying tef [Eragrostis tef (Zucc.) Trotter] accessions and varieties respectively. Furthermore, we thank Professor Tekalign Mamo and Mr. Sintayehu Hundie for their constructive advice and comments.

\section{REFERENCE}

Abel, H. G \& MacKenize J. A. 1964. Salt tolerance of soybean varieties (Glycine Max L.) during germination and later growth. Crop Science, 4(2):1053-1056. 
Azhar, M. F \& McNeilly, T. 1987. Variability for salt tolerance in Sorghumn bicolor (L.) Moench under hydroponic conditions. J. Agronomy and Crop Science, 159: 269277.

Ashraf, M \& McNeilly, T. 1988. Variability in salt tolerance of nine spring wheat cultivars. J. Agronomy and Crop Science, 160:14-21.

Ashraf, M \& Waheed, A. 1992. Screening chickpea (Cicer arietinum L.) for salt tolerance. J. Agriculture in the Tropics and Subtropics, 93:45-55.

Ashraf, M \& Waheed, A. 1993. Resposes of some local/exotic accessions of lentil (Lens culinaris Medic.) to salt stress. J. Agronomy and Crop Science, 170:103-112.

Brady N C \& Weil, R. R. 2002. The Nature and Properties of Soils. $13^{\text {th }}$ Edition. Prentice-Hall, Upper Saddle Rivers, New Jersey.

Central Statistical Authority. 2004. Agricultural Sample Survey 2003/2004, Volume I. Report on Area and Production of Crops (Private Peasant Holdings, Meher Season). Statistical Bulletin 302, Addis Ababa, 127 pp.

Dudeck, A.E, Singh, S., Giordano, C.E., Neel, T. A \& McConnell, D.B. 1983. Effects of sodium chloride on cynodon turfgrasses. J. Agronomy, 75 (6):927-930.

EL-Khashab, A. A.M., Elaidy, A.A., EL-Sammak, A. F., Salama, M.I \& Rienger, M.1997. Paclobutrazol reduces some negative effects of salt stress in peach. J. Amer. Soc. Hort. Science, 122(1):43-46.

FAO/AGL. [Online] Available http://www.fao.orglag/agl/agll/spush/ topic? htm; November, 2000.

Fentaw Abegaz, 1995. Effects of subsurface drainage system on ground water table, soil salinity and crop yield in Melka Sadi Pilot drainage scheme. In: Woldeyesus Sinebo, Zerihun Tadele and Nigusie Alemayehu (Eds.), Increasing food production through improved crop management. Proceedings of the First and Inaugural Conference of the Agronomy and Crop Physiology of Ethiopia, 30-31 May 1995, IAR, Addis Ababa, Ethiopia,139-148 pp.

Francois, E. L., Donovan, T. J., Maas, E. V \& Rubenthaler, L. G. 1988. Effects of salinity on grain yield and quality, vegetative growth, and germination of Triticale. J. Agronomy, 80(4):642-647. 
Gorham, J \& Hardy, A. C. 1990. Response of Eragrostis tef to salinity and acute water shortage. J. Plant Physiology, 135(6):641-645.

Gupta, R \& Minhas P S. 1993. Managing salt affected waters for crop production. In: S.D. Singh (Ed.), Arid Land Irrigation and Ecological Management. Scientific Publishers, New Delhi, 159-198 pp.

Hailay Tsige, Tadele G/Sellasie \& Tekalign Mamo. 2000. Assessment of salinity/ sodicity problems in Abaya State Farm, Southern Rift Valley of Ethiopia. Ethiopian Journal of Natural Resources, 2(2):151-163.

Hailu Tefera \& Seyfu Ketema. 2000. Production and improvement of tef in Ethiopian agriculture. In: Hailu Tefera, Getachew Belay and M.Sorrells (Eds.), Narrowing the Rift: Tef Research and Development. Proceedings of the International Workshop on Tef Genetics and Improvement, 16-19 October 2000, Addis Ababa, Ethiopia.

Horst, G. L \& Dunning, N. B. 1989. Germination and seedling growth of perennial ryegrasses in soluble salts. J. Amer. Soc. Hort. Sci., 114(2):338-342.

Horst, G.L \& Taylor, R.M. 1983. Germination and initial growth of Kentucky blue grass in soluble salts. J. Agronomy, 75(4):679-681.

Hunt, O. J. 1965. Salt tolerance in intermediate wheatgrass. Crop Sci., 5(5):407-409.

Lee, K. S., Choi, Y. S \& Choi, Y. W. 1998. Varietal difference in salinity tolerance during germination stage of rice. Korean J. Crop Science, 43 (1):11-14.

Lemma Desalegne. 1996. Salt Tolerance in Tomatoes (Lycopersicon esculentum Hill). A Thesis Submitted by lemma Deslegne for the Degree of Doctor of Philosophy. Department of Agricultural Botany, School of Plant Science, University of Reading, 245 pp.

Marambe, B \& Ando, T. 1995. Physiological Basis of Salinity Tolerance of Sorghum Seeds during Germination. J. Agronomy and Crop Science, 174:291-296.

Marler, T. E \& Mickelbart, M. V. 1993. Growth and chlorophyll fluorescence of Spondias Purpurea L. as influenced by salinity. Tropical Agriculture (Trinidad), $70(3): 245-247$. 
Mengesha Haile Melak, Pickett, C. R \& Davis, L. R. 1965. Genetic variability and interrelationship of characters in tef, Eragrostis tef (Zucc.) Trotter. Crop Science, 5(1): 155-157.

Norlyn, D. J \& Epstein, E. 1983. Variability in salt tolerance of four triticale lines at Ggermination and emergence. Crop Science, 24:1090:1092.

Purseglove, J. W. 1972. Tropical Crops: Monocotyledons. Longman Group Limited London. 607 pp.

Seyfu Ketema. 1993. Tef [Eragrosits tef), Breeding, Agronomy, Genetic Resources, Utilization and Role in Ethiopian Agriculture. Institute of Agricultural Research, 102 pp.

Singh, J. N., Sharma, D. K \& Chillar, R. K. 1999. Forage yield and chemical composition of pearl millet (Pennisetum typhodes) as influenced by exchangeable sodium. J. Agric. Sci. Camb., 111(3):465-467.

Suhayda, C. G., Redmann, R.E., Harvey, B. L \& Cipywnyk, A. L. 1992. Comparative response of cultivated and wild barely species to salinity stress and calcium supply. Crop Science, 32(1):154-163.

Tadelle Gebresellassie, 1993. Degradation problems of irrigated agriculture: In: Soil-the Resource Base for Survival. Proceedings of the Second Conference of ESSS, 2324 September 1993, Addis Ababa., Ethiopia, 199-206 pp.

Tekalign Mamo, Richter, C \& Heiligatag B. 1996. Response of some varieties of durum wheat and tef to salt stress. J. African Crop Sciences, 4(4):423-432.

Verma, S. P. O \& Yadava, R. B. R. 1986. Salt tolerance of some oats (Avena sativa L.) varieties at germination and seedling stage. J. Agronomy and Crop Science, 156:123-127. 